\title{
Efficacy of tranexamic acid in reducing blood loss during lower segment caesarean section
}

\author{
Vijayalaxmi Raghavendra Gobbur, Shobha Shivanand Shiragur*, \\ Usha R. Jhanwar, Manpreetkaur Jaspal Tehalia
}

\begin{abstract}
Department of Obstetrics and Gynaecology, Bijapur Liberal District Educational University's Shri B.M. Patil Medical College, Hospital and Research Centre, Bijapur-586103, Karnataka, India
\end{abstract}

Received: 5 May 2014

Accepted: 23 May 2014

\section{*Correspondence:}

Dr. Shobha Shivanand Shiragur,

E-mail: shiragur1208@gmail.com

(C) 2014 Gobbur VR et al. This is an open-access article distributed under the terms of the Creative Commons Attribution Non-Commercial License, which permits unrestricted non-commercial use, distribution, and reproduction in any medium, provided the original work is properly cited.

\begin{abstract}
Background: Objective of current study was to study the efficacy of tranexamic acid in reducing blood loss during and after lower segment caesarean section.

Methods: A randomized, case controlled, prospective study was conducted on 100 women undergoing lower segment caesarean section (LSCS between Oct 2007 and Oct 2009). Fifty of them were given tranexamic acid 1 gm slow IV 20 minutes before LSCS \& were compared with 50 others to whom tranexamic acid was not given. Blood loss was collected and measured during two periods. The first period was from placental delivery to end of LSCS and second from the end of LSCS to 2 hours postpartum.

Results: Tranexamic acid significantly reduced the quantity of blood loss during LSCS $289.4 \pm 71.4$ ml in the study group versus $328 \pm 58.9 \mathrm{ml}$ in the control group $(\mathrm{P}=0.004)$. It also significantly reduced the quantity of blood loss from placental delivery to 2 hours post-partum: $360.9 \pm 110.3 \mathrm{ml}$ in the study group, versus $443 \pm 88.55 \mathrm{ml}$ in the control group. $(\mathrm{P}=0.0008)$. No complications or side effects were reported in either group.

Conclusions: Tranexamic acid significantly reduces the blood loss during and after the caesarean section. Side effects like nausea, vomiting, diarrhoea \& thrombosis are rare. Tranexamic acid can be used effectively in women undergoing LSCS to decrease the blood loss.
\end{abstract}

Keywords: Tranexamic acid, Caesarean section, Antifibrinolytic agent

\section{INTRODUCTION}

Cesarean section rates have increased to as high as 25 $30 \%$ in many areas of the world. ${ }^{1}$ Delivery by CS can cause more complications than normal vaginal delivery and one of the most common complications is primary or secondary hemorrhage. In order to reduce maternal mortality and morbidity caused by bleeding it is important to reduce the maternal bleeding during and after lower segment cesarean section. ${ }^{1}$ Concerns about blood safety continual blood shortages and rising cost of blood bank operations have generated interest in the reduction of transfusion requirements during and after surgery. A popular approach is to minimize peri operative bleeding through the prophylactic use of antifibrinolytic agents such as aprotinin, tranexamic acid and amino caproic acid. ${ }^{2}$ Tranexamic acid is a synthetic derivative of the amino acid lysine that exerts its antifibrinolytic effect through the reversible blockade of the lysine binding sites on the plasminogen molecules. ${ }^{3,4}$ Intravenous administration of the tranexamic acid has been routinely used for many years to reduce hemorrhage during and after surgical procedures like coronary artery bypass, scoliosis surgery, oral surgery etc. In this study the efficacy of tranexamic acid in reducing the blood loss during and after LSCS in two periods the First period was from placental delivery to end of LSCS and Second from the end of LSCS to 2 hours postpartum, and the efficacy 
of tranexamic acid in reducing incidence of post-partum haemorrhage and the adverse drug reactions associated with use of tranexamic acid were investigated.

\section{METHODS}

It is prospective randomized case control study done from October 2007 to October 2009. Hundred pregnant women undergoing LSCS in Shri B.M. Patil medical college hospital and research centre were included in this study. They were randomly allocated in to two groups, study group and control group. The study group comprise 50 subjects who received tranexamic acid and 50 subjects who did not receive tranexamic acid formed the control group.

For the study group subjects tranexamic acid injection was given 20 minutes before incision as $1 \mathrm{gm} / 10 \mathrm{ml}$ with additional dilution of $10 \mathrm{ml}$ IV slowly infused over 5 minutes. After delivery of neonate oxytocin 10 units in a pint of DNS was given by intravenous drip over 30 minutes, while $0.2 \mathrm{mg}$ methyl ergometrine was given by slow IV. The control group subjects did not receive tranexamic acid but 10 unit oxytocin and $0.2 \mathrm{mg}$ methyl ergometrine were given like in the study group. The subjects with medical or surgical problem involving heart, liver and kidney, H/O thrombo embolic disorder, abnormal placentas such as placenta previa, placental abruption, pre-eclampsia, multiple pregnancy, macrosomia and polyhydramnios, complication with myoma were excluded from the study.
Amount of blood loss was calculated as follows. The quantity of blood $(\mathrm{ml})=($ Weight of guaze pads used after surgery - weight of guaze pads used prior to surgery) + (The volume of blood in suction bottle after placental delivery). In addition the sanitary pads used after completion of LSCS to 2 hour postpartum were separately weighed.

\section{Statistical analysis}

Data was analyzed using statistical methods 1) Mean \pm SD 2) ' $Z$ ' test.

\section{RESULTS}

This is a prospective randomised case control study done from October 2007 to October 2009. 100 pregnant women undergoing LSCS in Shri B M Patil medical college hospital and research centre were included in this study.

50 women comprised study group-subjects who received tranexamic acid and 50 women comprised control groupsubject who did not receive tranexamic acid.

Table 1 shows that the possible confounding variables like age, height, weight are matched effectively in both the groups.

Table 1: Distribution based on patient characteristics in both groups.

\begin{tabular}{|lllll|}
\hline & $\begin{array}{l}\text { Study group } \\
(\text { Mean } \pm \text { SD) } \\
\mathbf{n}=\mathbf{5 0}\end{array}$ & $\begin{array}{l}\text { Control } \\
(\text { Mean } \pm \text { SD) } \\
\mathbf{n}=\mathbf{5 0}\end{array}$ & $\mathbf{Z}$ test & P value \\
\hline Age (years) & $23.62 \pm 3.429$ & $24.5 \pm 3.982$ & $\mathrm{Z}=1.19$ & $\mathrm{P}=0.239 \mathrm{NS}$ \\
\hline Height $(\mathrm{cm})$ & $152.56 \pm 5.75$ & $153.2 \pm 6.0$ & $\mathrm{Z}=0.54$ & $\mathrm{P}=0.588 \mathrm{NS}$ \\
\hline Weight $(\mathrm{kg})$ & $52.54 \pm 7.86$ & $53.5 \pm 7.45$ & $\mathrm{Z}=0.63$ & $\mathrm{P}=0.532 \mathrm{NS}$ \\
\hline
\end{tabular}

Table 2: Distribution with respect to indications for LSCS in both groups.

\begin{tabular}{|lll|}
\hline Indication of LSCS & $\begin{array}{l}\text { Study group } \\
\text { (no. of cases) }\end{array}$ & $\begin{array}{l}\text { Control group } \\
\text { (no. of cases) }\end{array}$ \\
\hline Primi C breech & 5 & 3 \\
\hline Fetal distress & 17 & 19 \\
\hline Pre LSCS C CPD & 13 & 15 \\
\hline $\begin{array}{l}\text { Pre LSCS with } \\
\text { abnormal presentation }\end{array}$ & 5 & 3 \\
\hline $\begin{array}{l}\text { Cephalopelvic } \\
\text { disproportion }\end{array}$ & 4 & 3 \\
\hline $\begin{array}{l}\text { Pre LSCS with scar } \\
\text { tenderness }\end{array}$ & 3 & 5 \\
\hline Arrest of descent & 3 & 2 \\
\hline
\end{tabular}

Table 2 shows distribution according to indication of LSCS in both the groups. There was no statistical significance in indication of LSCS between the two groups. The indication of LSCS can have baring on amount of intraoperative blood loss. The fact that these were matched adequately in the study group removes the effect of these confounding variables.

Table 3 shows mean blood loss from time of placental delivery to completion of skin closure was 289.4 in the study group\& it was $328.4 \mathrm{ml}$ in the control group $\mathrm{P}$ value being 0.004 , suggesting that there was statistically highly significant difference in blood loss in both the groups. Patients who received tranexamic acid have 40 
ml less blood loss than patients who didn't received tranexamic acid. Table 3 shows mean blood loss from time of completion of skin closure to 2 hours postpartum was $75.5 \mathrm{ml}$ in the study group and it was $112.6 \mathrm{ml}$ in the control group $\mathrm{P}$ value being 0.0002 , suggesting that there was statistically highly significant difference in blood loss in both the groups. Patient who received tranexamic acid has $50 \mathrm{ml}$ less blood loss than patients who didn't received tranexamic acid.

Table 3: Effect of tranexamic acid: comparison of blood loss.

\begin{tabular}{|lllll|}
\hline Mean blood loss (ml) & Study group & Control group & $\mathbf{Z}$ test & P value \\
\hline $\begin{array}{l}\text { From time of placental delivery to } \\
\text { completion of skin closer }\end{array}$ & $289.4 \pm 71.4$ & $328.4 \pm 58.9$ & 2.98 & $\begin{array}{l}0.004 \\
\text { Highly significant }\end{array}$ \\
\hline $\begin{array}{l}\text { From completion of skin closer to } \\
\text { 2 hours postpartum }\end{array}$ & $71.5 \pm 53.6$ & \multirow{2}{*}{$112.6 \pm 51.7$} & \multirow{2}{*}{3.9} & $\begin{array}{l}0.0002 \\
\text { Highly significant }\end{array}$ \\
\hline
\end{tabular}

Table 4 shows incidence of blood loss $>500 \mathrm{ml}$ in both the groups. Patients who received tranexamic acid had $18 \%$ less incidence of blood loss $>500 \mathrm{ml}$ than patients who didn't received tranexamic acid, $\mathrm{P}$ value being 0.002 , the difference was found to be statistically significant.

Table 4: Effect of tranexamic acid: comparison of incidence of patient with blood loss $>500 \mathrm{ml}$ in both groups.

\begin{tabular}{|lllll|}
\hline & $\begin{array}{l}\text { Study } \\
\text { group }\end{array}$ & $\begin{array}{l}\text { Control } \\
\text { group }\end{array}$ & Z test & P value \\
\hline $\begin{array}{l}\text { Blood loss } \\
(>500 \mathrm{ml})\end{array}$ & $6(12 \%)$ & $15(30 \%)$ & 2.27 & $\mathrm{P}=0.02$ \\
\hline
\end{tabular}

Table 5 shows adverse drug reaction due to use of tranexamic acid. The incidence of the side effects like nausea, vomiting \& diarrhoea were not increased in the study group as compared to the control group suggesting that the use of tranexamic acid had no significant adverse drug reaction.in addition there was no increase in incidence of thrombosis in study group.

Table 5: Comparing adverse drug reaction in the two groups.

\begin{tabular}{|lllll|}
\hline & Study & Control & Z test & P value \\
\hline Nausea & 16 & 13 & 0.66 & $0.508 \mathrm{NS}$ \\
\hline Vomiting & 09 & 08 & 0.08 & $1.135 \mathrm{NS}$ \\
\hline Diarrhoea & 01 & 00 & 1.01 & $0.312 \mathrm{NS}$ \\
\hline $\begin{array}{l}\text { Signs of } \\
\text { thrombosis }\end{array}$ & 00 & 00 & & \\
\hline
\end{tabular}

\section{DISCUSSION}

Tranexamic acid exerts its antifibrinolytic effect by blocking the lysine binding locus of the plasminogen and plasmin molecules, thereby preventing the binding of the plasminogen and plasmin to the fibrin substrate. Tranexamic acid also inhibits conversion of plasminogen to plasmin by plasminogen activators. ${ }^{3,4}$ During placental delivery fibrinogen and fibrin are rapidly degraded whereas plasminogen activators and fibrin degradation products (FDP) increase due to activation of the fibrinolytic system. This activation can last upto 6-10 hours post-partum causing more bleeding. It was because of this activation of the fibrinolytic system that we decided to use tranexamic acid the trial.

Our study showed that tranexamic acid significantly reduces bleeding from the time of placental delivery to 2 hours postpartum in LSCS. Results show that the study group patients had reduction in the blood loss by $20 \%$ and also tranexamic acid also reduces the incidence of post-partum hemorrhage by $18 \%$. Similar study carried out by Ming-Ying Gai, Lian-Fang Wu and co-workers ${ }^{5}$ in China showed blood loss reduction by $30 \%$ as compared to control group and also reduced the incidence of postpartum hemorrhage by $25.7 \%$. These results co related well with our study.

Zheng SR, Yang HX et al. ${ }^{6}$ showed similar results. The incidence of thrombosis during pregnancy \&puerperium is 5-6 times higher than that in general population. When the antifibrinolytic drug tranexamic acid is administered, increased risk of thrombosis should be considered, especially in the LSCS postpartum population. In our study, not a single patient developed signs of thrombosis.

Suanberg \& coworkers $^{7}$ reported 67 cases treated by tranexamic acid because of abruptio placenta \& thrombosis occurred in none of the cases. Beskassy Z, Astedt $A{ }^{8}$ included 3014 women including 45 pregnant women and gave tranexamic acid to prevent bleeding at conisation of cervix, thromboembolic episodes were absent.

Ming Ying Gai, Ling fang Wu \& coworkers ${ }^{5}$ in china in their study of tranexamic acid in LSCS also showed that no thrombosis in study group. The side effects of tranexamic acid as nausea, vomiting \& diarrhoea were not statistically significant in both the groups in our study. These results were similar with previous studies. 
All data demonstrated that tranexamic acid can be used safely without increasing the occurrence of thrombosis, but still need more cases to be observed for occurrence of thrombosis.

\section{CONCLUSION}

Tranexamic acid significantly reduces the amount of blood loss during \& after the LSCS. Its use is not associated with increased risk of adverse drug reaction like nausea, vomiting, diarrhoea or thrombosis. Tranexamic acid can be used safely during LSCS to reduce the blood loss.

\section{ACKNOWLEDGEMENTS}

The authors express gratefulness to the Dept. of OBG, BLD University's Shri B M Patil Medical College, Bijapur for providing facility to publish this article.

Funding: No funding sources Conflict of interest: None declared

Ethical approval: The study was approved by the institutional ethics committee

\section{REFERENCES}

1. Kambo I, Bedi N, Dhillon BS, et al. A critical appraisal of caesarean section rates at teaching hospitals in India. Int J Gynaecol Obstet. 2002 Nov;79:151-8.

2. Tidsskr Nor Taegeforen. Haemorrhage in LSCS. J Obstet Gynaecol. 2000 Oct;120(24):2864-6.
3. Thorsen S. Differences in the binding to fibrin of native plasminogen modified by proteolytic degradation: influence of E-aminocaproic acids. Biochem Biophys Acta. 1975;393:55-65.

4. Hoylaerts M, Linjen HR, Colleen D. Studies on mechanism of antifibrinolytic action of tranexamic acid. Biochem Biophys Acta. 1981;673:75-85.

5. Miya-ying Gai, Lian-fang $\mathrm{Wu}$, Qi-fengs Su. A clinical observation of blood loss reduced by tranexamic acid during \& after caesarean section: A multi-centre randomized trial. Eur J Obstet Gynaecol Reprod Biol. 2004;112(2):154-7.

6. Zheng SR, Yang HX et al. Clinical study on the efficacy of tranexamic acid in reducing postpartum blood loss. Chin J Obstet Gynaecol. 2001;36:59.

7. Svanberg L, Astedt B, Nilsson IM. Abruptio placentae treatment with the fibrinolytic inhibitor tranexamic acid was effective. Acta Obstet Gynaecol Scand. 1980;59:127-30.

8. Bekassay Z, Astedt B. Treatment with fibrinolytic inhibitor tranexamic acid: risk for thrombosis? Acta Obstet Gynaecol Scand. 1990;69:353-4.

9. Zheng SR, Yang HX et al. Clinical study on the efficacy of tranexamic acid in reducing postpartum blood lose: a randomized, comparative, multicenter trial. Zhonghua $\mathrm{Fu}$ Chan $\mathrm{Ke} \mathrm{Za}$ Zhi. 2001 Oct;36(10):590-2.

DOI: $10.5455 / 2320-1770 . i j r \operatorname{cog} 20140626$

Cite this article as: Gobbur VR, Shiragur SS, Jhanwar UR, Tehalia MJ. Efficacy of tranexamic acid in reducing blood loss during lower segment caesarean section. Int J Reprod Contracept Obstet Gynecol 2014;3:414-7. 